\title{
Blossom blight resistance in peach: heritability and segregation in progenies from reciprocal crosses $^{1}$
}

\author{
Maximiliano Dini ${ }^{2,4 *}$, Maria do Carmo Bassols Raseira ${ }^{3}$, Bernardo Ueno ${ }^{3}$
}

$10.1590 / 0034-737 X 202168060007$

\begin{abstract}
Blossom blight and brown rot caused by Monilinia fructicola is the most important peach disease in Brazil. Genetic resistance is a control strategy that is gaining importance in breeding programs worldwide. This study aimed to identify genotypes with higher levels of blossom blight resistance to estimate the heritability of this character; study the frequency distribution in populations; and test the possibility of maternal effect. Blossom blight susceptibility was tested in reciprocal hybridizations seedlings, as well as their parents. The detached flower technique was used in a randomized complete block design, considering each genotype as a treatment. Flower inoculation was made by spraying a M. fructicola suspension and evaluations were carried out after 72 and 120 hours using a scale of five severity levels. The studied populations presented low phenotypic variability regarding the flower resistance/susceptibility to $M$. fructicola, being most of them susceptible or very susceptible. Among the tested genotypes, the cultivars Maciel and Cerrito showed less blossom blight susceptibility, transmitting this character to their progenies. Heritability estimates of the blossom blight resistance were medium to low. The low heritability and its distribution in the progenies suggest that the character has additive inheritance, without detecting deviations associated with maternal effects.
\end{abstract}

Keywords: Prunus persica (L.) Batsch; Monilinia fructicola (Winter) Honey; genetic resistance.

\section{INTRODUCTION}

The fungus Monilinia fructicola (Winter) Honey, is the most important pathogen of the peach culture in Brazil, as well as in other producing regions of the world due to the large losses it may cause, when its control is incorrectly done (Adaskaveg et al., 2008; Agrios, 1998; Fortes \& Martins, 1998; May-de Mio et al., 2008, 2014; Ogawa et al., 1995). This pathogen may attack the peach during the whole cycle, but especially during flowering and fruit ripening, which are the most susceptible phases (Bleicher, 1997; May-de Mio et al., 2014). The disease cycle begins during flowering, causing blossom blight. Normally necrotic flowers remain attached to the branch, which may be infected by the fungus, resulting in cankers and twig blight (May-de Mio et al., 2008, 2014; Mondino et al., 2010). The blossom blight is the primary infection of the disease and has great epidemiological importance, since it is an inoculum source for secondary infections in the fruits, directly by the production of conidia or in form of latent infections on the fruit in formation, or developing only during the ripening stage of the fruit (Garcia-Benitez et al., 2016; 2017; May-de Mio et al., 2014; Mondino et al., 2010; Thomidis, 2017). The first symptoms observed in fruits (brown rot) are small and circular brown spots. At the maturation stage, infected fruits develop a firm rot, brown lesion that advances rapidly, covering the entire fruit. On the lesion, the fungus sporulation appears powdery and grayish color (May-de Mio et al., 2014; Mondino et al., 2010).

Under mild temperature, humid and rainy weather conditions, this disease can cause total crop loss and, in an attempt to reduce these losses, growers may weekly

\footnotetext{
Submitted on September 23 $3^{\text {th }}, 2020$ and accepted on March 14 th, 2021.

${ }^{1}$ This work is part of the master's [support of Agencia Nacional de Investigación e Innovación (ANII) - Uruguay] and doctoral [support of Coordenação de Aperfeiçoamento de Pessoal de Nível Superior (CAPES) - Brazil] thesis of the first author.

Universidade Federal de Pelotas, Faculdade de Agronomia Eliseu Maciel, Programa de Pós-Graduação em Agronomia, Pelotas, Rio Grande do Sul, Brazil.

${ }^{3}$ Embrapa Clima Temperado, Pelotas, Rio Grande do Sul, Brazil. maria.bassols@embrapa.br; bernardo.ueno@embrapa.br

${ }^{4}$ Instituto Nacional de Investigación Agropecuaria (INIA), Programa Nacional de Investigación en Producción Frutícola, Estación Experimental INIA Las Brujas, Canelones, Uruguay. mdini@inia.org.uy

*Corresponding author: mdini@inia.org.uy
} 
apply fungicides. Nowadays, with the increasing concern about the environment and the health of growers and consumers (Baró-Montel et al., 2019; Elshafie et al., 2015), as well as the occurrence of fungus strains resistant to the main used fungicide molecules (Luo et al., 2010; Hily et al., 2011; Zhu et al., 2012; Chen et al., 2017; Fu et al., 2017) the importance of other control strategies is emphasized. Among them, genetic resistance is the most efficient way to control the disease, reducing production costs and environmental impact.

The selection of resistant genotypes is still very limited due to the lack of knowledge of high resistance or immunity sources (Raseira \& Franzon, 2014). The resistance to M. fructicola is a quantitative and polygenic trait in peach, considered as a character of difficult transmission from the parents to the progenies and highly influenced by the environment (Wagner Júnior et al., 2005; Raseira \& Franzon, 2014). However, there are significant differences in susceptibility among the available genotypes (Adaskaveg et al. 2008; Santos \& Ueno, 2014).

There are evidences that there is no correlation between flower and fruit resistance (Fabiane, 2011; Santos et al., 2012; Wagner Júnior et al., 2005). In cv. Bolinha for example, that has been widely studied as a standard of brown rot resistance, there was low level of resistance in flowers, unlike to the reaction in fruits (Santos et al., 2012). Therefore, the selection of resistant genotypes must be done independently, for the blossom blight and brown rot in fruits (Raseira \& Franzon, 2014; Wagner Júnior et al., 2005), however there are few studies focused on resistance in flowers. Thus, the aims of this work were: to identify genotypes with higher levels of resistance in flowers; to estimate the heritability; to study their distribution in populations; and to test the possibility of maternal effect.

\section{MATERIAL AND METHODS}

\section{Plant material}

The study was performed at Embrapa Clima Temperado, in Pelotas, RS, Brazil (31 ${ }^{\circ} 40^{\prime}$ 'S, 52 $26^{\circ}$ 'W, 57 masl), in the years 2015 and 2016. The susceptibility to blossom blight in peaches was tested in reciprocal hybridizations seedlings ( $F_{1}$ progenies), as well as on their parents. The reciprocal $\mathrm{F}_{1}$ progenies used were: 2008.159 (Conserva $1526 \times$ 'Cerrito') and 2009.38 ('Cerrito' × Conserva 1526); 2012.26 (Cascata $1055 \times$ 'Chimarrita') and 2012.43 ('Chimarrita' $\times$ Cascata 1055); 2012.49 (Conserva $672 \times$ Conserva 1526) and 2012.61 (Conserva $1526 \times$ Conserva 672); 2012.52 (Conserva $947 \times$ Conserva 1600) and 2012.66 (Conserva $1600 \times$ Conserva 947); 2012.68 (Conserva 1662 × 'Maciel') and 2012.88 ('Maciel' $\times$ Conserva 1662). The progenies had a minimum of seven and a maximum of 25 evaluated seedlings.
It should be noted that the phytosanitary management of peach seedlings, in the Embrapa Clima Temperado breeding program, is restricted to fungicide applications in the winter period, except in years of extreme weather conditions (such as excess rain). During spring and summer, only insecticides are applied to pest management, aiming to select less susceptible seedlings to the main pathogens, as M. fructicola.

\section{Experimental design and treatments}

For testing the reaction to blossom blight, the technique of detached flowers cited by Fabiane (2011) was used as the most efficient technique to this purpose. The experiment was arranged in a randomized complete block design, considering each genotype as one treatment (seedlings and parents). For the seedling 12 flowers were inoculated, divided into three replicates of four flowers. In the case of the parents, there were three plants obtained by budding (clones) in which three replicates of four flowers were evaluated per clone. Four more flowers per genotype (or clone) without inoculation (control), were also observed to estimate the proportion of latent inoculum coming from the field. The selections Conserva 655 and Cascata 1055 were used as standard of high and low susceptibility to blossom blight, respectively (Fabiane, 2011). The cultivar Bolinha, standard of resistance to M. fructicola in fruits, was also included.

\section{Pathogen culture, conidia productMion, and inoculation}

The fungus isolate was obtained from mummified fruits, infected by $M$. fructicola, collected at four different sites of Embrapa Clima Temperado peach orchards (Pelotas, RS, Brazil). From these, fragments of approximately $5 \mathrm{~mm}$ were collected and transferred to Petri dishes containing Potato Dextrose Agar (PDA) culture medium and incubated in a growth chamber at $25 \pm 2{ }^{\circ} \mathrm{C}$ for seven to ten days, with 12 hours light. Contamination with other fungi or bacteria was eliminated by successive passages until the pure culture was obtained. The obtained fungus isolate was stored in test tubes with PDA culture medium in a cold chamber $\left(4 \pm 1^{\circ} \mathrm{C}\right)$. Whenever necessary, the fungus was cultured on ripe peach fruits and then, re-inoculate in Petri dishes with PDA.

The conidia were removed from the cultures of $M$. fructicola with seven to ten days of incubation, with a brush and $10 \mathrm{~mL}$ of distilled water. The suspension was then filtered and the concentration of conidia was determined using an optical microscope and a Neubauer chamber. The concentration was adjusted to $1 \times 10^{5}$ conidia $\mathrm{mL}^{-1}$ (Fabiane, 2011; Santos et al., 2012; Wagner Júnior et al., 2005). 
Productive branches containing flower buds at half inch green and pink stages, stages 3 and 4 according to Chapman \& Catlin (1976), were collected from the individual plants to be tested. The branches were prepared by removing opened or damaged flowers and were kept in buckets with water, inside a cold room during 48 hours at 4 $\pm 1^{\circ} \mathrm{C}$, in order to standardize flowering (Santos et al., 2012), and also to avoid or reduce the contamination with pathogens (Luo et al., 2010; May-de Mio et al., 2008). After 48 hours in the cold chamber, the branches were left for another 24 hours at room temperature for the opening of flowers (anthesis). Finished this period, 16 opened flowers, without disease symptoms, were selected from each branch group. Plastic boxes $(50 \times 35 \times 10 \mathrm{~cm})$ with phenolic foam with cells $(2.5 \times 2.5 \times 3.8 \mathrm{~cm})\left(\right.$ Green-up $\left.{ }^{\circledR}\right)$ previously washed in running water for 30 minutes were used. One flower with a small portion of the twig was fixed in each cell.

The inoculation was done by spraying, using a fine droplet spray, with approximately $0.8 \mathrm{~mL}$ of the $M$. fructicola conidial suspension, per box (Fabiane, 2011; Santos et al., 2012) containing between 140 to 200 flowers. Adjustment of the spray volume was done using water-sensitive cards, aiming the correct coverage of flowers.

\section{Blossom blight evaluation}

After inoculation, the boxes with the flowers, were covered with a plastic bag and placed in a growth chamber (Fitotron), with $23^{\circ} \mathrm{C} \pm 1^{\circ} \mathrm{C}$ temperature, $75 \%$ humidity and $12 \mathrm{~h}$ light. After 72 and 120 hours, the incidence and severity of the blossom blight were evaluated. Those flowers with petals with necrotic spots were considered infected (Fabiane, 2011; Santos et al., 2012; Wagner Júnior, 2003). Severity was assessed on a grading scale from 0 to 4 (Table 1 and Figure 1).

The grading scale used (Table 1) was elaborated aiming at its ease use during evaluation. The scale limits that determine the scores correspond to the percentage of the flower area with the presence of necrotic spots. The limits described in the grading scale were transformed into a scale of figures (Figure 1), with the ImageJ program and photographs of flowers evaluated 72 and 120 hours after inoculation (hai) with $M$. fructicola, under the same conditions of the experiment. Therefore, the standard of this scale was specific for artificially inoculated flowers and under the conditions of this experiment.

\section{Statistical and genetic analysis}

To evaluate the segregation of the progenies and to test for the possibility of maternal effect influence, relative frequency histograms of the severity data were constructed. The maternal effect comparing the progeny of one of the crosses with the reciprocal progeny was also tested using the Mann-Whitney test at 5\% significance (Londero et al., 2009; Wu et al., 2012).

The variance observed between the three clones of each parent gave the environmental effect estimation, and the average of parents' variances was used as the estimated environmental variance $\left(\hat{\sigma}_{\mathrm{e}}^{2}\right)$. The observed variance among plants of the same progeny was used as the total estimated phenotypic variance $\left(\hat{\sigma}_{\mathrm{p}}^{2}\right)$. The estimated genetic variance $\left(\hat{\sigma}_{\mathrm{g}}^{2}\right)$ was calculated by subtracting the environmental variance from the phenotypic variance of each progeny. Broad-sense heritability $\left(H^{2}\right)$ for the character of resistance to blossom blight was estimated dividing the genetic variance of each population by the total variance of the same population. The calculation was based on the data obtained in the two evaluation seasons, so was divided by two (number of environments) (Dirlewanger et al., 2012; Griffiths et al., 2015):

\section{RESULTS AND DISCUSSION}

A high variability in the incidence of blossom blight in non-inoculated flowers (field infestation) was detected. This fact was indicated by the high phenotypic variance observed, mainly, in the evaluation after 72 hours, among the evaluated individuals . which was 1015.07 and 610.53 for progenies, and 1144.94 and 729.66 for parents, in the years of 2015 and 2016, respectively (Table 2). This shows the presence of inoculum in the orchard during blossom.

The variability among the studied genotypes can be explained by the different levels of susceptibility to the disease associated with the genotype, by differences in blossom time (temporal) and geographic location within the Embrapa orchard (spatial) (Santos et al., 2012). The high incidence of blossom blight, even without a previous inoculation has already been reported (Keske et al., 2010; Santos et al., 2012) and is due to the high pressure of natural inoculum present in peach orchards in southern Brazil (Fortes \& Martins, 1998; May-de Mio et al., 2008; 2014) and favorable climatic conditions for the disease at flowering season (Figure 2).

It was possible to evaluate the reaction to $M$. fructicola in flowers of 129 and 148 seedlings in 2015 and 2016, respectively. Nine parents of those seedlings progenies plus the genotypes Conserva 655 and 'Bolinha' were evaluated in both years. The lack of data for all individuals available is due to the fact that many of them did not bloom (either by age, plant size, or adverse climatic factors) or the flowers were not in adequate condition during the experiment period. The vegetative cycle of 2015 and 2016 was characterized by the occurrence of higher temperatures during the flowering period (July to August), and high rainfall (Figure 2), conditions that favored the incidence of $M$. fructicola on flowers. There 
were cases in which the samples had to be discarded due to the high level of infection in flower buds coming from the orchard.

The score range for the disease incidence was the maximum possible (0 to $100 \%$ incidence) in flowers without inoculation, in the evaluations performed in the $72 \mathrm{~h}$ and in the two years of evaluation, for both, progenies and parents. For the inoculated flowers the score, after 72 hours, also ranged from 0 to $100 \%$ in the year 2015 , however in 2016, it was between 50 and $100 \%$ and 44.44 to $100 \%$, for the progenies and parents respectively (Table 2).

The phenotypic variability regarding resistance/ susceptibility to $M$. fructicola in inoculated flowers was low, with most genotypes being classified as susceptible or very susceptible to the disease. These genotypes presented overall averages of incidence between 86.94 and 96.94\% (72 hai), and between 91.71 and $99.28 \%$ (120 hai). The overall averages of severity degree were between 1.36 and 2.24 (72 hai), and between 2.54 and 3.48 (120 hai) (Tabela 2).

Analyzing the percentage of lesions incidence in the flowers of the selections and cultivars tested without inoculation, the genotypes with the lowest incidence were 'Maciel', Conserva 672, Conserva 1526, 'Cerrito' and Cascata 1055 with less than $65 \%$ when evaluated at 72 hours, and less than $80 \%$ when evaluated at 120 hours (Figure 3).

When inoculated, the genotypes that presented the lowest susceptibility were 'Maciel' and 'Cerrito', with 55.88 e $77.78 \%$ average incidence, respectively, in the evaluation performed 72 hai (Figure 3). The selection Cascata 1055, used as a control of low susceptibility, showed an incidence of $86.11 \%$, therefore, higher than the two cultivars mentioned above and higher than the incidence reported by Fabiane (2011), which was 30.10\%. The cultivar Bolinha, presented a high incidence $(94.44 \%)$, similar to that obtained by Santos et al. (2012). The high incidence observed suggests that all the studied genotypes present high susceptibility to the disease under the tested conditions.

In addition to the genetic component, this may occur due to the influence of several factors, such as: very high conidia concentration used $\left(1 \times 10^{5}\right.$ conidia $\left.\mathrm{mL}^{-1}\right)$, susceptible phenological state (open flower), incubation conditions favorable to the disease and high presence of inoculum in the field.

In the evaluation performed at 120 hai, only the cultivars Maciel and Cerrito had an incidence lower than $90 \%$, while most of the genotypes showed around $100 \%$ incidence. Thus the evaluation at 120 hai, under the tested conditions, did not differentiate the genotypes (Figure 3).

'Cerrito', Cascata 1055 and 'Maciel' presented the highest percentage of flowers (considering the two years of evaluation) within categories 0 and 1 (severity scale), with $64.89,80.95$ and $93.55 \%$, respectively, in the evaluation performed 72 hai (Figure 4). When evaluated at 120 hai, only the cultivars 'Cerrito' and 'Maciel' presented a considerable percentage within these categories, 28.17 and $44.44 \%$, respectively.

The progenies 2008.159, 2009.38, 2012.68 and 2012.88 presented the lowest incidence $(<85 \%)$ and severity ( $\mathrm{Fi}$ gure 4). This indicates that the less susceptible 'Cerrito' and 'Maciel', used as parents transmitted this trait to their

Table 1: Grading scale for assessing the severity of the blossom blight in peach

\begin{tabular}{ll}
\hline Score & Description \\
\hline 0 & Without infection \\
1 & Necrotic spots on the petals covering $>1 \%$ d" $20 \%$ of the surface \\
2 & Necrotic spots on the petals $>20 \% \leq 40 \%$ \\
3 & Necrotic spots on the petals $>40 \% \leq 60 \%$ \\
4 & Necrotic spots on the petals $>60 \%$ \\
\hline
\end{tabular}

0

1

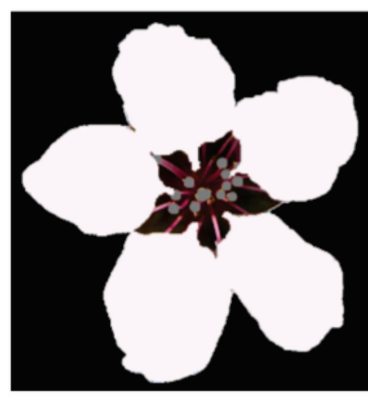

Without infection
Scale

2

3

4

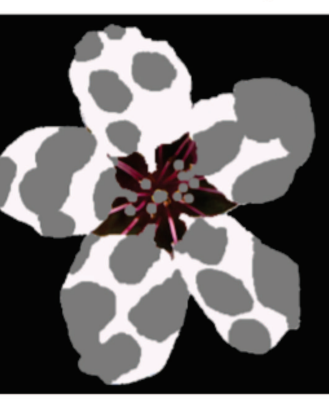

$60 \%$ of necrotic spots

Figure 1: Severity scale used to evaluate the blossom blight in peach flowers artificially inoculated by spraying.

Rev. Ceres, Viçosa, v. 68, n.6, p. 555-563, nov/dec, 2021 
progeny. This can be verified, since in the first two progenies 'Cerrito' is one of the parents, as well as 'Maciel' for the last two.

The severity scale of blossom blight was not fully efficient to quantify susceptibility to $M$. fructicola. This was evidenced by the lack of normal distribution in the histograms of relative frequencies (Figure 4). When evaluated 72 hai most of the genotypes remained in category 1 (necrotic spots covering between $1 \%$ and $20 \%$ of the petals) (Table 1). Similarly, when evaluations were performed 120 hai, most genotypes were located in the category 4 (necrotic spots covering more than $60 \%$ of the petals) (Table 1). This suggests that there should be more categories between these percentages to segregate more levels of severity to the disease. Although this have not great practical importance, it is interesting in the epidemiology of the disease since genotypes that develop infections and sporulations more rapidly, increase the rate of disease dissemination (May-de Mio et al., 2014; Mondino et al., 2010; Rios \& Debona, 2018).

Observing the histograms, different behavior was not evident when a genitor was used as female or male parent, leading to the conclusion that there is no maternal effect. (Dini et al., 2019). The hypothesis of maternal effect in the five reciprocal crosses studied was tested through the

Table 2: Descriptive statistics of the variables incidence and severity of blossom blight in 10 reciprocal peach progenies and their parents, evaluated after 72 and 120 hours, with and without artificial inoculation, in the years 2015 and 2016, Embrapa Clima Temperado, Pelotas, Rio Grande do Sul, Brazil

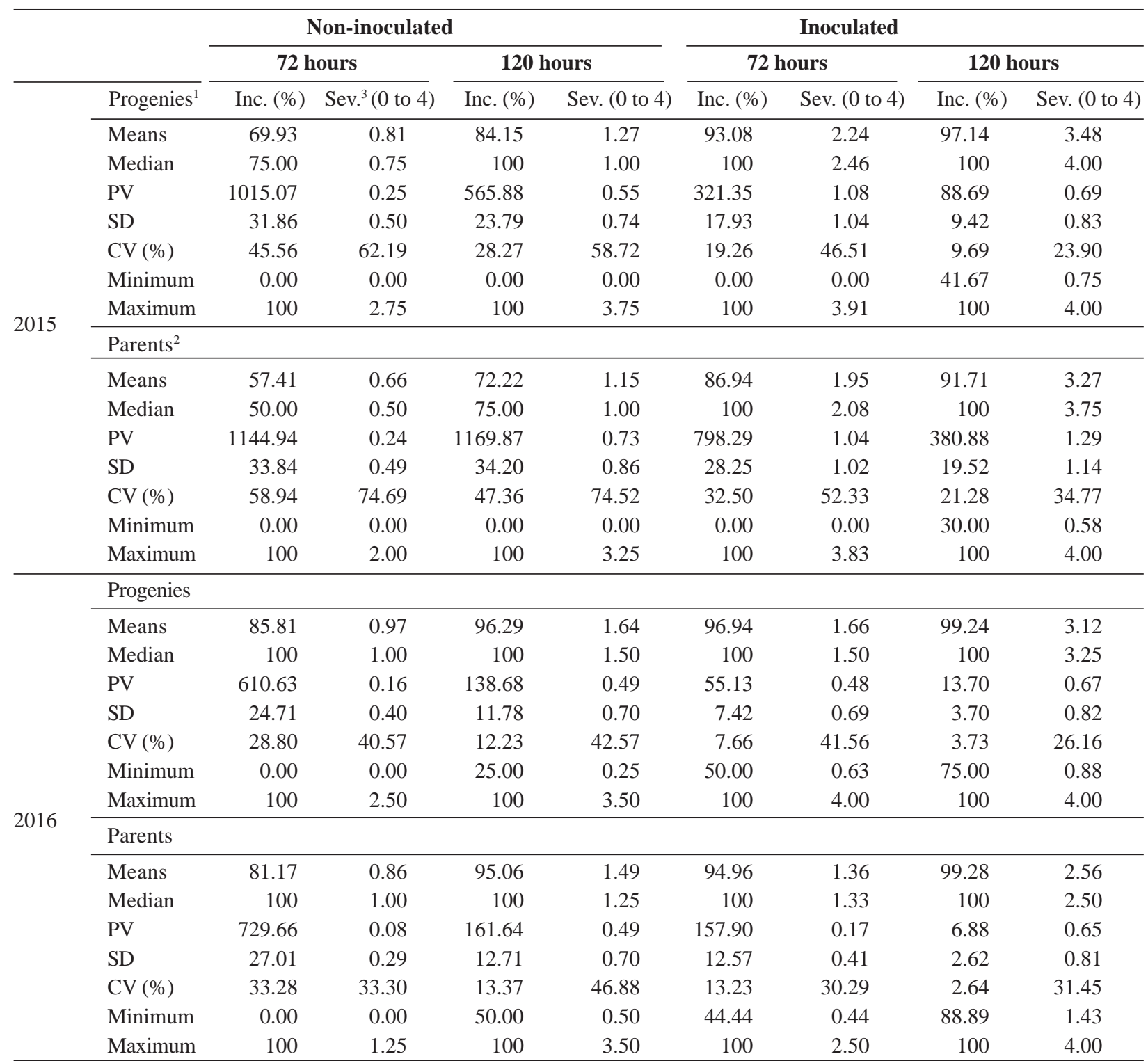

${ }^{1}$ Results of 129 e 148 different genotypes belonging to $F_{1}$ progenies, in the 2015 and 2016 seasons, respectively; ${ }^{2} 9$ parental genotypes were evaluated (advanced selections and cultivars); ${ }^{3}$ Scale of 0 to 4 as being 0 petals without lesions and 4 petals with $60 \%$ or more of the area with lesions. $\mathrm{PV}=$ phenotypic variance; $\mathrm{SD}=$ standard deviation; $\mathrm{CV}=$ coefficient of variation. 
Mann-Whitney test. The tested contrast, in all cases, was F1 progeny versus its reciprocal F1 progeny for the studied parameters (incidence and severity).The test was not significant $(p>0.05)$, for any of the progenies, that is, there were no significant differences between the reciprocal progenies, indicating that there is no maternal effect on the transmission of this trait (Dini et al. 2019; Londero et al.; 2009).

The estimated $\mathrm{H}^{2}$ values were medium to low, varying between 11 and $43 \%$, depending on the studied population, with an average of $24 \%$ for incidence and $17 \%$ for severity.

In the study of Wagner Júnior (2003) in which the $\mathrm{H}^{2}$ for blossom blight was estimated through the incidence, the values ranged between 6 and $66 \%$, depending on the studied population, with averages between 30 and $42 \%$. This same author also concluded that the $\mathrm{H}^{2}$ for this trait is low and highly variable among populations.
Further studies aiming at adjusting a phenotyping protocol for this character become necessary to be able to correctly differentiate genotypes with different levels of genetic resistance. This should include mainly, studies related to the concentration of conidia to be used, phenological state of the flower, as well as the elaboration of a scale of severity more efficient to differentiate the genotypes.

On the other hand, the high latent infection in noninoculated flowers, leads to conclude that a good treatment and sanitary practices should be used in commercial orchards, whereas a source of high resistance level to blossom blight is not available. Moreover, for rapid screening of seedlings, the field conditions are sufficient to cause a high level of infection and select the least susceptible to be further evaluated with artificial inoculation, reducing significantly the number of individuals to be tested.

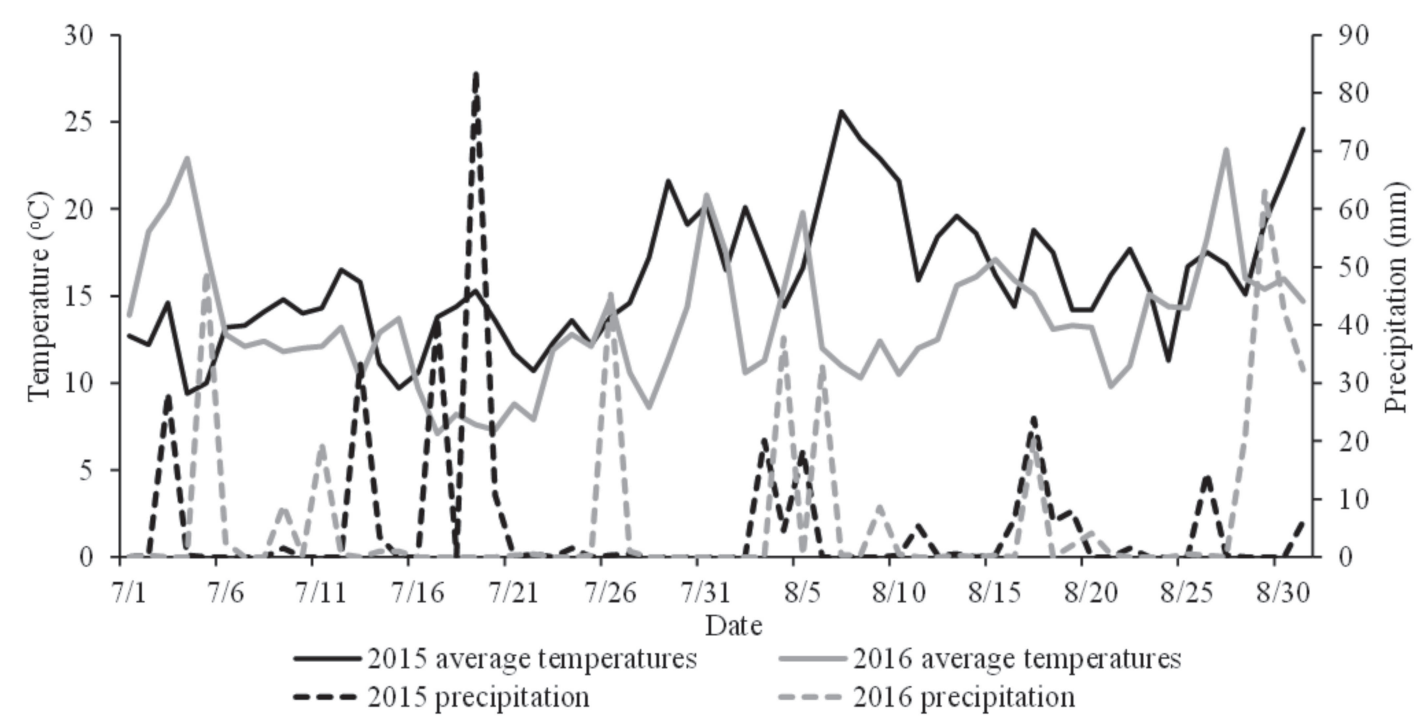

Figure 2: Average temperatures and daily rains in July and August of 2015 and 2016, Embrapa Clima Temperado, Pelotas, Rio Grande do Sul, Brazil. Source: AGROMET/CPACT/EMBRAPA (2018).

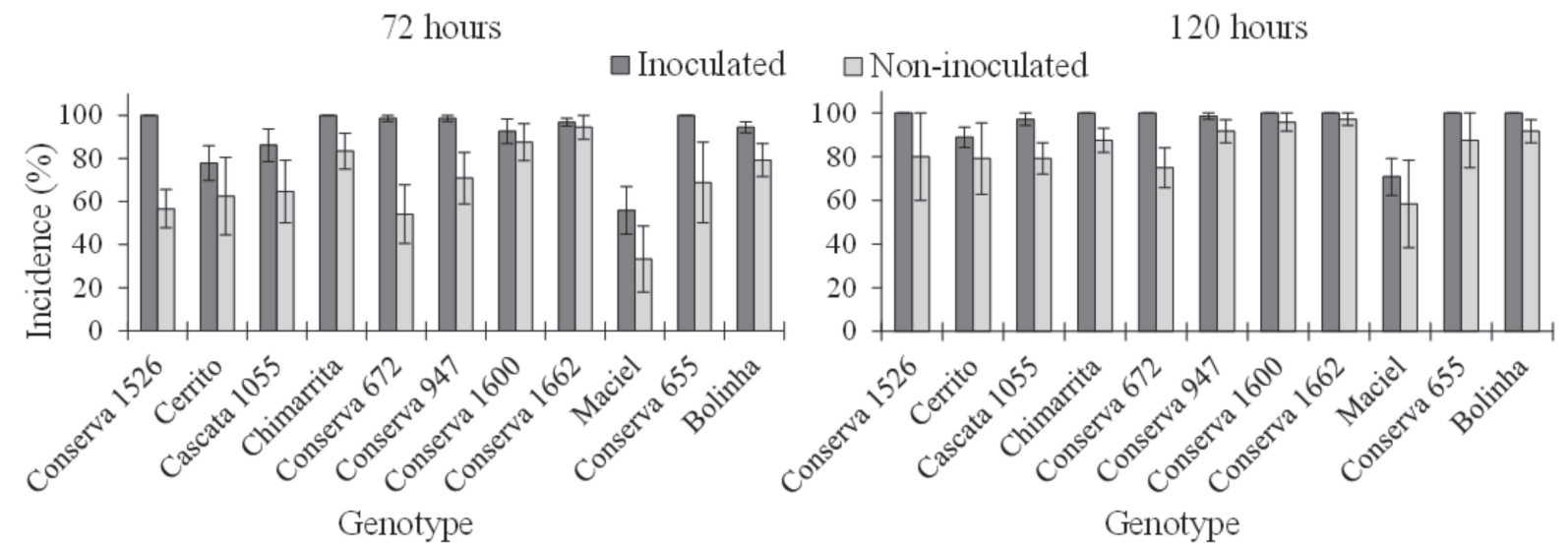

120 hours

Figure 3: Blossom blight incidence in peach genotypes submitted or not to $M$. fructicola inoculation, evaluated after 72 and 120 hours. The columns correspond to the average of two harvest seasons (2015 and 2016) and the vertical bars in each column refer to the standard error. Embrapa Clima Temperado, Pelotas, Rio Grande do Sul, Brazil. 


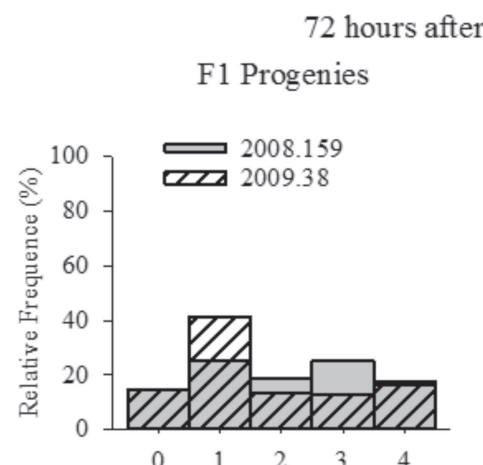

\section{inoculation}
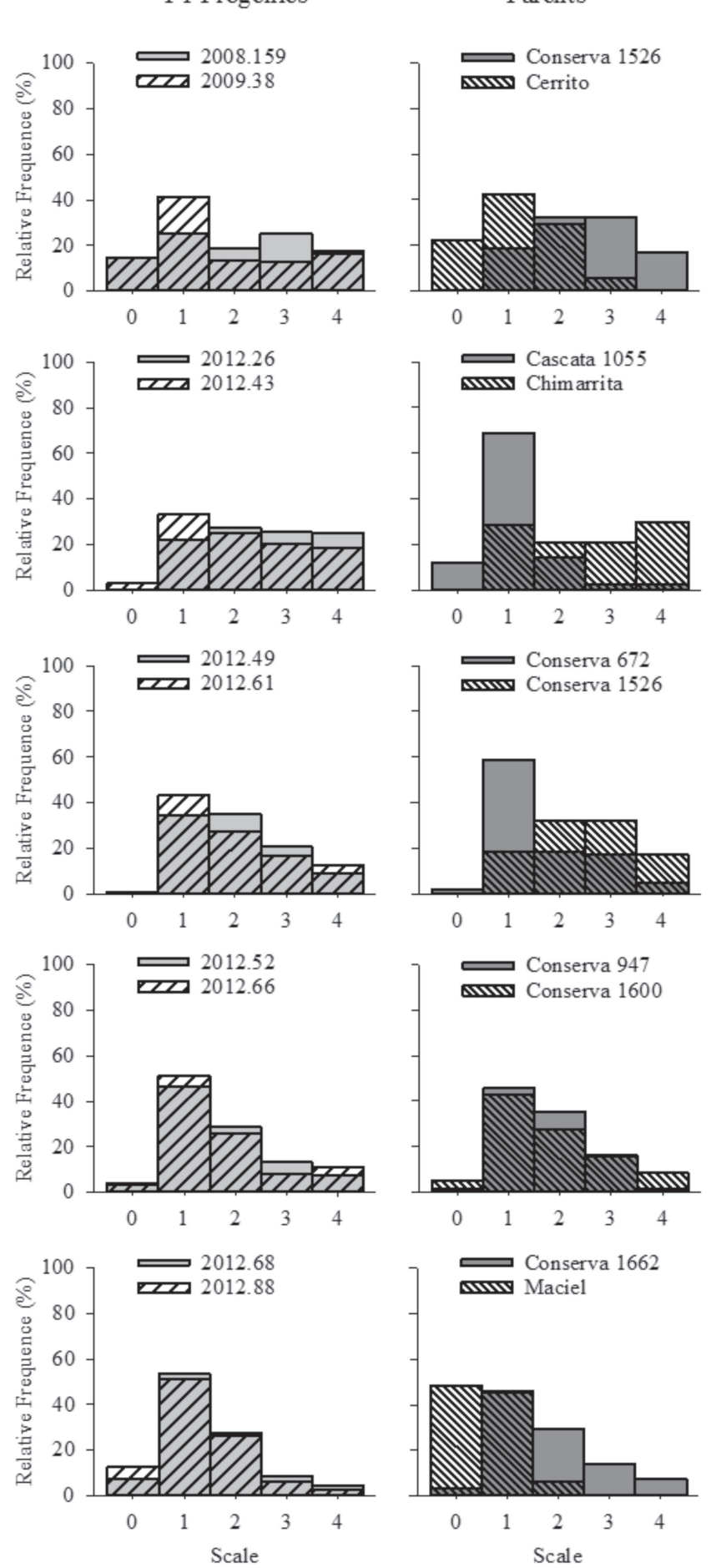
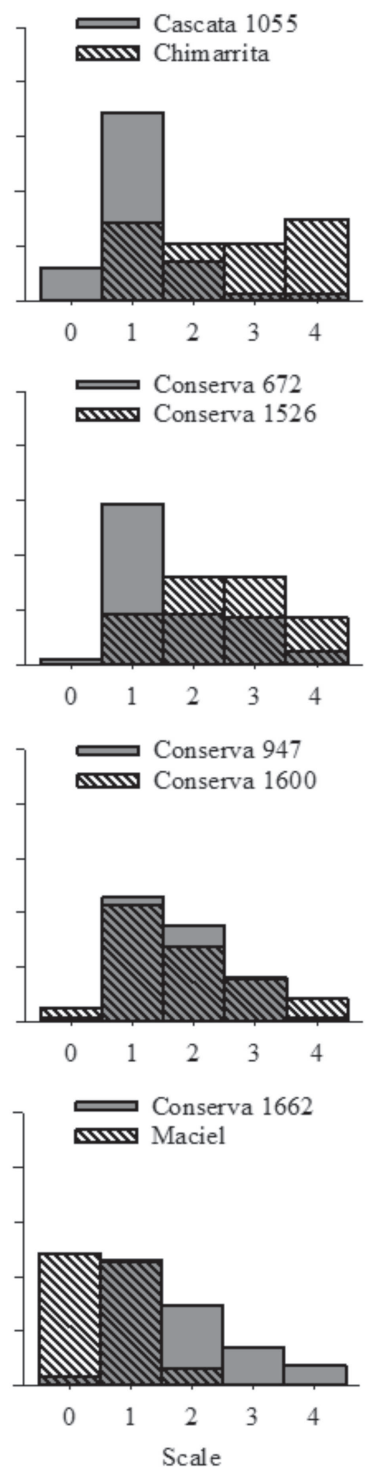

120 hours after inoculation

F1 Progenies

Parents
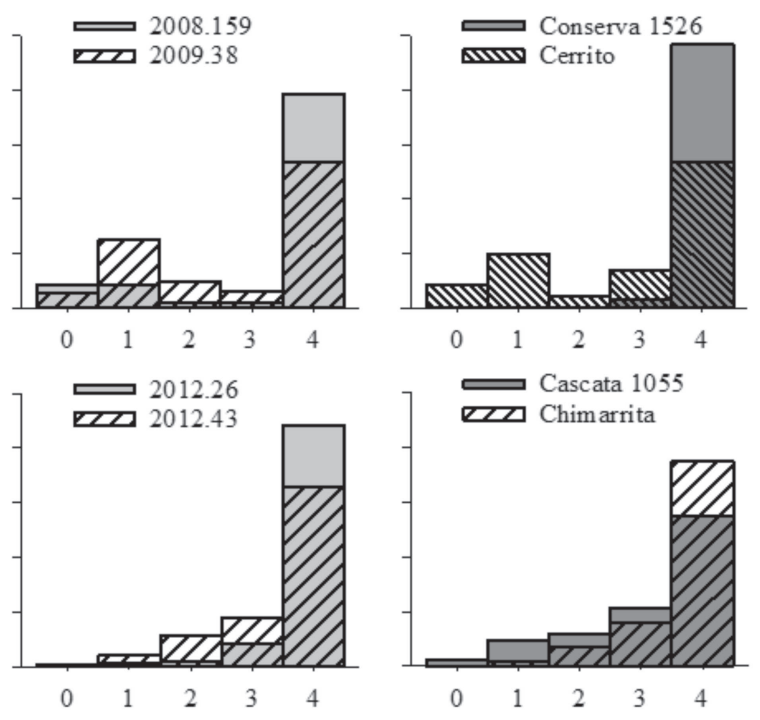

Cascata 1055
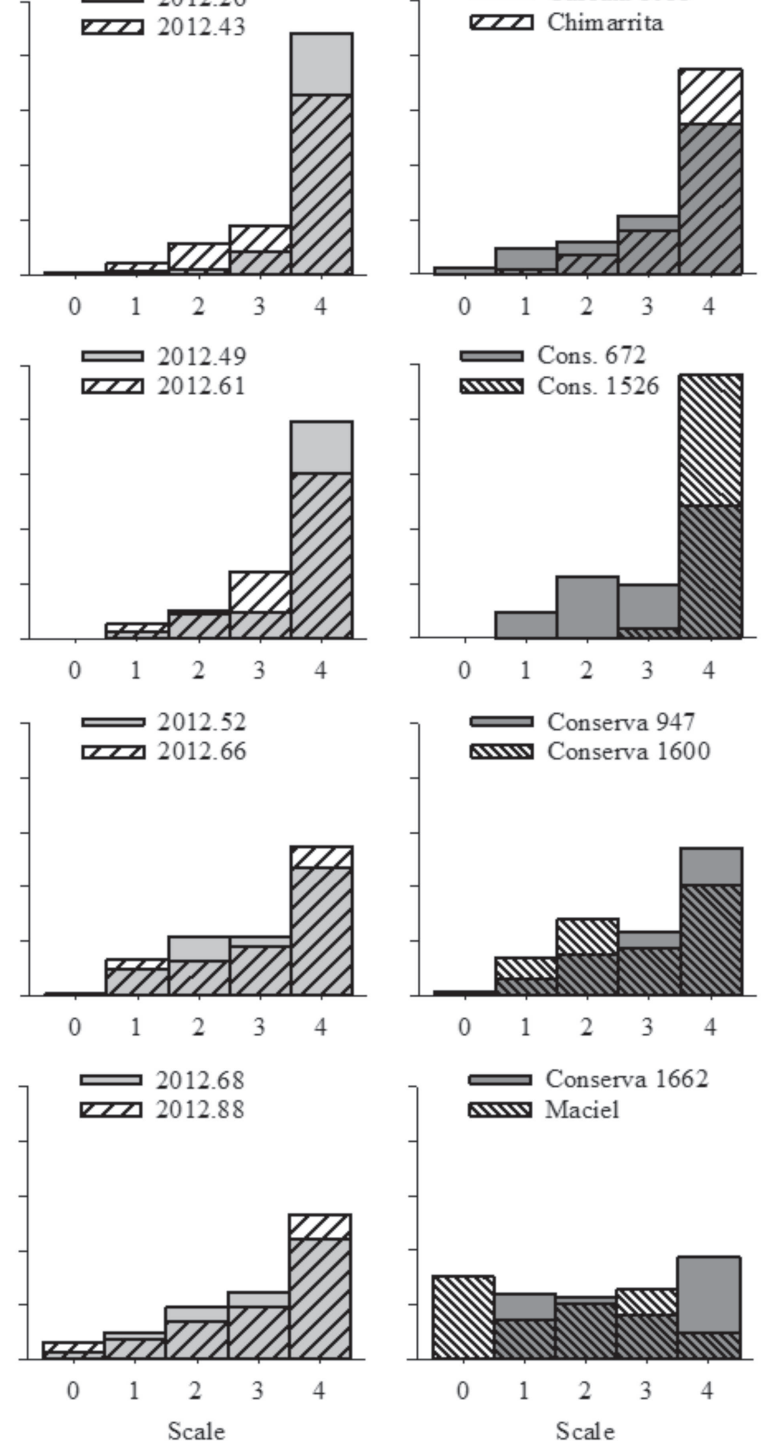

Figure 4: Severity of blossom blight in Fl progenies and their parents inoculated with $M$. fructicola and evaluated 72 and 120 hours after inoculation, years 2015 and 2016. The severity scale used ( 0 to 4) is detailed in Table 1 and in Figure 1. Embrapa Clima Temperado, Pelotas, Rio Grande do Sul, Brazil.

\section{CONCLUSIONS}

The studied populations presented low phenotypic variability regarding to resistance/susceptibility to Monilinia fructicola, with most genotypes being susceptible or very susceptible.
The cultivars Maciel and Cerrito are less susceptible to blossom blight, transmitting this character to their progenies.

The heritability of the resistance to blossom blight in peach is medium to low. 
No maternal effect on the transmission of susceptibility to blossom blight was detected.

Future studies should aim at adjust a phenotype protocol for this character, mainly related with the conidia concentration to be inoculated, as well as the elaboration of a more detailed scale of disease severity, in order to accurately differentiate genotypes with different levels of susceptibility.

\section{ACKNOWLEDGEMENTS, FINANCIAL SUPPORT AND FULL DISCLOSURE}

This study was partially funded by the Agencia Nacional de Investigación e Innovación-Uruguay (ANII) in the first year and by the Coordenação de Aperfeiçoamento de Pessoal de Nível Superior-Brazil (CAPES) in the second year. The authors thank Embrapa Clima Temperado and all its staff, especially Everton Pederzolli and Gilberto Kuhn for their assistance in the experiments. The authors have no conflicts of interest regarding the manuscript.

\section{REFERENCES}

Adaskaveg JE, Schnabel G \& Forster H (2008) Diseases of peach caused by fungi and fungal-like organisms: biology, epidemiology and management. In: Layne DR \& Bassi D (Eds.) The peach: botany, production and uses. Wallingford, CAB International. p. 352-406.

Agrios GN (1998) Plant diseases caused by fungi. In: Agrios GN (Ed.) Plant Pathology. New York, Academic Press. p.336-339.

Baró-Montel N, Eduardo I, Usall J, Casals C, Arús P, Teixidó N \& Torres R (2019) Exploring sources of resistance to brown rot in an interspecific almond $\times$ peach population. Journal of the Science of Food and Agriculture, 99:4105-4113.

Bleicher J (1997) Doenças de rosáceas de caroço. In: Kimati H, Amorim L, Bergamin Filho A, Camargo LEA \& Rezende JAM (Eds.) Manual de fitopatologia. São Paulo, CERES. p.621-627.

Chapman PJ \& Catlin GA (1976) Growth stages in fruit trees from dormant to fruit set. New York's Food and Life Sciences Bulletin. Available at: https://ecommons.cornell.edu/handle/ 1813/5062. Accessed on: April 20 2016.

Chen S, Yuan N, Schnabel G \& Luo C (2017) Function of the genetic element 'Mona' associated with fungicide resistance in Monilinia fructicola. Molecular Plant Pathology, 18:90-97.

Dini M, Raseira MCB, Scariotto S, Carra B, Abreu ES, MelloFarias P \& Cantillano RFF (2019) Color shade heritability of peach flesh. Journal of Agricultural Science, 11:236-247.

Dirlewanger E, Quero-García J, Le Dantec L, Lambert P, Ruiz D, Dondini L, Illa E, Quilot-Turion B, Audergon JM, Tartarini S, Letourmy P \& Arús P (2012) Comparison of the genetic determinism of two key phenological traits, flowering and maturity dates, in three Prunus species: peach, apricot and sweet cherry. Heredity, 109:280-292.

Elshafie HS, Mancini E, Camele I, De Martino L \& De Feo V (2015) In vivo antifungal activity of two essential oils from Mediterranean plants against postharvest brown rot disease of peach fruit. Industrial Crops and Products, 66:11-15.

Fabiane KC (2011) Reação de pessegueiros a Monilinia fructicola (Wint.) Honey e sua relação com componentes bioquímicos. Master Dissertation. Universidade Tecnológica Federal do Paraná, Pato Branco. 130p.
Fortes JF \& Martins OM (1998) Sintomatologia e controle das principais doenças. In: Medeiros CAB \& Raseira MCB (Eds.) A cultura do pessegueiro. Brasília, Embrapa-SPI/Embrapa-CPACT. p. 243-260.

Fu W, Tian G, Pei Q, Ge X \& Tian P (2017) Evaluation of berberine as a natural compound to inhibit peach brown rot pathogen Monilinia fructicola. Crop Protection, 91:20-26.

Garcia-Benitez C, Melgarejo P, De Cal A \& Fontaniella B (2016) Microscopic analyses of latent and visible Monilinia fructicola infections in nectarines. PLoS ONE, 11:e0160675.

Garcia-Benitez C, Melgarejo P \& De Cal A (2017) Detection of latent Monilinia infections in nectarine flowers and fruit by qPCR. Plant Disease, 101:1002-1008.

Griffiths AJF, Wessler SR, Carroll SB \& Doebley J (2015) Introduction to Genetical Analysis. $10^{\text {th }}$ ed. New York, W. H. Freeman and Company. 896p.

Hily JM, Singer SD, Villani SM \& Cox KD (2011) Characterization of the cytochrome b (cyt b) gene from Monilinia species causing brown rot of stone and pome fruit and its significance in the development of QoI resistance. Pest Management Science, $67: 385-396$

Keske C, Amorim L, Biasi LA \& May-de Mio LL (2010) Blossom blight and brown rot on organic peach production system. $\mathrm{Ci}$ ência Rural, 40:1682-1688.

AGROMET/CPACT/EMBRAPA (2018) Laboratório de Agrometeorologia, Embrapa Clima Temperado. Available at: http:// agromet.cpact.embrapa.br/. Accessed on: June 18 ${ }^{\text {th }}, 2018$.

Londero PMG, Ribeiro ND, Cerutti T, Mazeiro SM, Rosa DP \& Rosa SS (2009) Maternal effect in sulfur amino acids content expression in common bean grains. Ciência Rural, 39:1884-1887.

Luo CX, Hu MJ, Jin X, Yin LF, Bryson PK \& Schnabel G (2010) An intron in the cytochrome $b$ gene of Monilinia fructicola mitigates the risk of resistance development to Qol fungicides. Pest Management Science, 66:1308-1315.

May-de Mio LL, Moreira LM, Monteiro LB \& Justiniano Júnior PR (2008) Infection of Monilinia fructicola in budding stages and incidence of brown rot on fruits in two peach production systems. Tropical Plant Pathology, 33:227-234.

May-de Mio LL, Garrido LR, Ueno B \& Fajardo TVM (2014) Doenças da cultura do pessegueiro e métodos de controle. In: Raseira MCB, Pereira JFM \& Carvalho FLC (Eds.) Pessegueiro. Brasília, Embrapa. p.355-432.

Mondino P, Alaniz S \& Leoni C (2010) Manejo integrado de las enfermedades del duraznero en Uruguay. In: Soria J (Ed.) Manual del duraznero; Manejo integrado de plagas y enfermedades. Montevideo, INIA. p.45-76.

Ogawa JM, Zehr EI, Bird GW, Ritchie DF, Uriu K \& Uyemoto JK (1995) Compendium of stone fruit diseases. Saint Paul, The American Phytopathological Society. 98p.

Rios JA \& Debona D (2018) Efeito epidemiológico da resistência de hospdeiro. In: Dallagnol LJ (Ed.) Resistência genética de plantas a patógenos. Pelotas, UFPel. p.126-149.

Raseira MCB \& Franzon RC (2014) Melhoramento genético. In: Raseira MCB, Pereira JFM \& Carvalho FLC (Eds.) Pessegueiro. Brasília, Embrapa. p.57-72.

Santos J, Raseira MCB \& Zanandrea I (2012) Resistência à podridão-parda em pessegueiro. Bragantia, 71:219-225.

Santos J \& Ueno B (2014) Controle da podridão-parda no Brasil. In: Mitidieri M \& Castillo JA (Eds.) Manejo de la podredumbre morena (Monilinia fructicola y M. laxa) en huertos frutales de Uruguay, Chile, Bolivia, Brasil y Argentina. Santiago de Chile, CYTED - Red Frut-San. p.73-77. 
Thomidis T (2017) Influence of relative virulence and latent infections on the development of Monilinia to Greek peach orchards. Crop Protection, 94:159-165.

Wagner Júnior A (2003) Avaliação de germoplasma de pessegueiro, quanto à reação à Monilinia fructicola (Wint.) Honey. Master Dissertation. Faculdade de Agronomia Eliseu Maciel, Universidade Federal de Pelotas, Pelotas. 62p.

Wagner Júnior A, Raseira MCB, Fortes JF, Pierobom CR \& Silva JB (2005) Non-correlation of flower and fruit resistance to brown rot (Monilinia fructicola (Wint.) Honey) among 27 peach cultivars and selections. Journal of the American Pomological Society, 59:148-152.
Wu BH, Zhao JB, Chen J, Xi HF, Jiang Q \& Li SH (2012) Maternal inheritance of sugars and acids in peach (P. persica (L.) Batsch) fruit. Euphytica, 188: 333-345.

Zhu F, Bryson PK \& Schnabel G (2012) Influence of storage approaches on instability of propiconazole resistance in Monilinia fructicola. Pest Management Science, 68:1003-1009. 